Article

\title{
A Hybrid Multi-Criteria Decision-Making Model for Evaluating Companies' Green Credit Rating
}

\author{
Chia-Chen Yang ${ }^{1,+}$, Shang-Ling $\mathrm{Ou}^{2,+}$ and Li-Chang Hsu ${ }^{1, *}$ \\ 1 Department of Finance, Ling Tung University, Taichung 40852, Taiwan; ycc@teamail.ltu.edu.tw \\ 2 Department of Agronomy, National Chung Hsing University, Taichung 40227, Taiwan; \\ slou@dragon.nchu.edu.tw \\ * Correspondence: lchsu@teamail.ltu.edu.tw \\ + These authors contributed equally to this work.
}

Received: 17 January 2019; Accepted: 6 March 2019; Published: 13 March 2019

check for updates

\begin{abstract}
Along with economic development and social progress, environmental issues are increasingly becoming the subject of public concern. Through green credit, banks intentionally direct money into resource-conserving technology development and environmental protection industries, thus, encouraging enterprises to focus on green products. Therefore, establishing a reasonable green credit evaluation mechanism for banks is an important issue. Based on this, this study combines grey relational analysis (GRA), the Decision-Making Trial and Evaluation Laboratory technique (DEMATEL), analytic network process (ANP) and the Technique for Order of Preference by Similarity to Ideal Solution (TOPSIS) to develop a hybrid multi-criteria decision-making (MCDM) model for quantifying data and, thereby, to establish a green credit rating mechanism. In order to verify the model, this study combines credit risk and economic, environmental and social performance evaluation criteria as green credit evaluation criteria. There are 55 high-tech listed companies in Taiwan in 2014 taken as the evaluation objects and conducted for a performance ranking. The empirical results can serve as a reference for financial authorities promoting green finance policies and for investors making investment decisions.
\end{abstract}

Keywords: green credit rating; hybrid MCDM model; GRA; DEMATEL; ANP; TOPSIS

\section{Introduction}

In recent years, the concept of green sustainable development has been widely considered as an important issue in the world, and the economic orientation has gradually been replaced by the green. Economic transformation and upgrading require financial cooperation and support. Therefore, with green credit as the core, green finance has rapidly accelerated. Financial institutions use green credit as a way to drive economic transformation, are able to effectively resist environmental and social risks and can help transform into a green economy. For a long time, Taiwan's economic development has been at the expense of the environment, the overexploitation of land and natural resources, the ruthless destruction of ecosystems and the increasingly serious environmental pollution, which ultimately limits the continued development of the economy. In recent years, with the increasing global consensus on the development of green finance, Taiwan's green finance started relatively late compared to other countries. Although the government emphasizes the development of green finance, it has no specific results. Therefore, since 2015, Taiwan's commercial banks have incorporated the green credit into their credit policy for the first time. However, there is a lack of evaluation criteria and evaluation methods for green credit. For Taiwan, establishing a suitable green credit decision-making model is an urgent task. Therefore, the main purpose of this study is to establish a set of credit criteria for green credit and to conduct green credit evaluations and ranking with the proposed modified hybrid multi-criteria 
decision-making (MCDM) model. The results can be provided to the banking industry as a reference for corporate green credit assessment.

A credit rating is one of the most commonly used methods to assess the creditworthiness of a company. Traditional credit assessment methods do not consider that environmental and climate change may affect a company's credit risk assessment. These factors could lead to a potential impact on a bank's overall loan risk profile, and thus, traditional methods are not conducive to the development of green finance and green economy. Therefore, establishing a green credit rating model for commercial banks to determine lending policies is an important problem faced by financial institutions.

Traditionally, the banks investigate a company's financial situation and determines their credit rating. That is, they evaluate the performance of a company through a financial ratio analysis and use this analysis to measure the degree of credit risk. Eccles and Pyburn [1] argued that financial indicators play an important role in measuring company performance, but putting too much emphasis on financial performance also has its disadvantages. Traditional credit rating techniques emphasize the importance of financial indicators but do not include social and environmental factors. Adding these two types of indicators can result in great differences in the credit assessment of companies. Therefore, Weber et al. [2] indicated that financial institutions in Germany integrate corporate environmental performance into the credit risk rating process, and by incorporating sustainability indicators, a bank's risk management becomes more efficient.

In the 1990s, the concept of sustainable development gradually penetrated in various fields. Driven by environmental protection concepts, the financial industry and the concept of sustainable development became closely related. Based on the close relationship between the financial industry and business operations, the financial industry needs to pay attention to investment projects or whether the project complies with environmental protection policies in the credit decision-making process to avoid financial losses caused by environmental risks.

Green credit has gradually become a trend in most countries and has received more and more support and attention from financial institutions. Among them, "Equator Principles" have become one of the most well-known guidelines for banks. In the June 2013 version of the third version of the Equator Principles, there are 10 Equator Principles (see Appendix A). The Equator Principles require that commercial banks address environmental and social risks in project financing and emphasize the harmonious unity between a company's environmental protection, social development and economic development. It is a financial industry benchmark for determining, assessing and managing environmental and social risks in projects. Therefore, commercial banks have transformed the operating target of "maximizing shareholder value" into "full consideration to the demands of multi-stakeholder" development. On the Equator Principles website (https://equator-principles.com/), 94 financial institutions in 37 countries have adopted the Equator Principles as a reference for the green credit assessment guidelines. Since 2017, only four banks, including Cathay United Bank Co., Ltd., Taipei, Taiwan; CTBC Bank Co., Ltd., Taipei, Taiwan; E. SUN Commercial Bank, Ltd., Taipei, Taiwan; and Taipei Fubon Commercial Bank have adopted the Equator Principles as a reference for green credit evaluation. In terms of green finance, it has fallen far behind other countries and must catch up. Therefore, for the banking industry, a comprehensive set of green credit assessment criteria and evaluation is urgently needed.

The principles of sustainable development encompass the triple bottom line of thinking-economic, environmental and social aspects. With the development of risk management frameworks such as the Global Reporting Initiative (GRI) Standards and the Equator Principles, the global economy is gradually leading a shift to sustainable development. Through the implementation of green credit, the banking industry guides the flow of funds and resource allocation and achieves sustainable development under the premise of the triple bottom line of the environment, society and economy. Therefore, green credit requires commercial banks to take a "triple bottom line" approach to managing business. That is, commercial banks not only do business to meet the needs of partners but also realize that their behavior must consider society and the environment. When a bank 
makes a green credit assessment of a company, a number of evaluation criteria must be considered comprehensively. Therefore, the green credit assessment for companies is a MCDM problem.

In previous studies, different MCDM methods have been used in the credit rating decision analysis. Past works have mainly focused on evaluating the financial performance of a company. Rather than using just a single financial ratio, performance evaluation methods have begun to combine patterns of financial indicators and nonfinancial indicators to comprehensively evaluate company performance. Currently, the MCDM method is widely used in evaluating and ranking problems [3-6].

Lots of MCDM techniques are available in the literature. However, policy makers do not have a specific rule for choosing techniques. This is because different MCDM methods are suited to solving different kinds of problems. In recent years, a hybrid MCDM model combining the Decision-Making Trial and Evaluation Laboratory technique (DEMATEL) with the analytic network process (ANP) and VlseKriterijumska Optimizacija I Kompromisno Resenje (VIKOR) (or Technique for Order of Preference by Similarity to Ideal Solution (TOPSIS)) methods has been widely used in multi-criteria decisions [7-10]. However, while the above method is suitable for the qualitative analysis of questionnaire data, it cannot be applied to quantitative data. Therefore, this study proposes a modified hybrid MCDM model for quantitative data analysis and applies it to assess banks' green credit decision analyses.

The aim of this study is to establish a suitable modified hybrid MCDM model that can be used for quantitative data analysis. First, the grey relational analysis (GRA) in grey theory is employed here to measure the degree of correlation between the indicators. Then, we use the DEMATEL method to establish a system structure model. Next, ANP is used to obtain criteria weights. Finally, the TOPSIS method is used for the green credit assessment and to determine the ranking of the companies. According to the abovementioned approach, this study establishes a green credit evaluation model for banks. However, there is always a risk in the evaluation of a model. In order to help reduce this risk, a sensitivity analysis of the model parameters is conducted in this study.

In the past few decades, the electronics industry was an important growth engine for the Taiwanese economy. Taiwan's electronics industry is a high-tech, high-value-added and capital-intensive industry. It plays an important role in the production process (OEM/ODM) of the global electronics industry supply chain system. Manufacturing processes in the electronics industry consume energy and produce pollution. Moreover, production processes are often accompanied by toxic contamination as well as a high consumption of water and energy. The 1997 Kyoto Protocol focuses on the issue of environmental protection, including governments' environmental policies and companies' business strategies, and certain measures must be taken in response. In terms of environmental policy, due to stricter waste emissions standards, many companies face restrictions in production that affect production and production scheduling. Therefore, issues of environmental protection must be considered to maintain business continuity.

In the 21st century, green credit is an important economical means of controlling pollution and protecting the environment. Thus, this type of credit has become an inevitable trend in the future development of banks. In the process of bank financing of companies, an emphasis is placed on environmental protection and ecological environmental governance by directing social and economic resources that can promote the sustainable development of society. A bank can guide social capital flows, prompt companies to take measures to reduce environmental pollution and tap into new energy social, thereby changing social and economic development. Green credit is an important trend in the development of modern finance and is also an effective way for banking financial institutions to fulfill their social responsibility.

Therefore, this study uses Taiwan's listed electronics companies as the research object to evaluate banks' work on green credit and to confirm the feasibility of the proposed hybrid MCDM model. The results can be used as a reference for banks in green credit decision-making and for approving companies' loans. The evaluation procedure of this study consists of several steps as shown in Figure 1. 


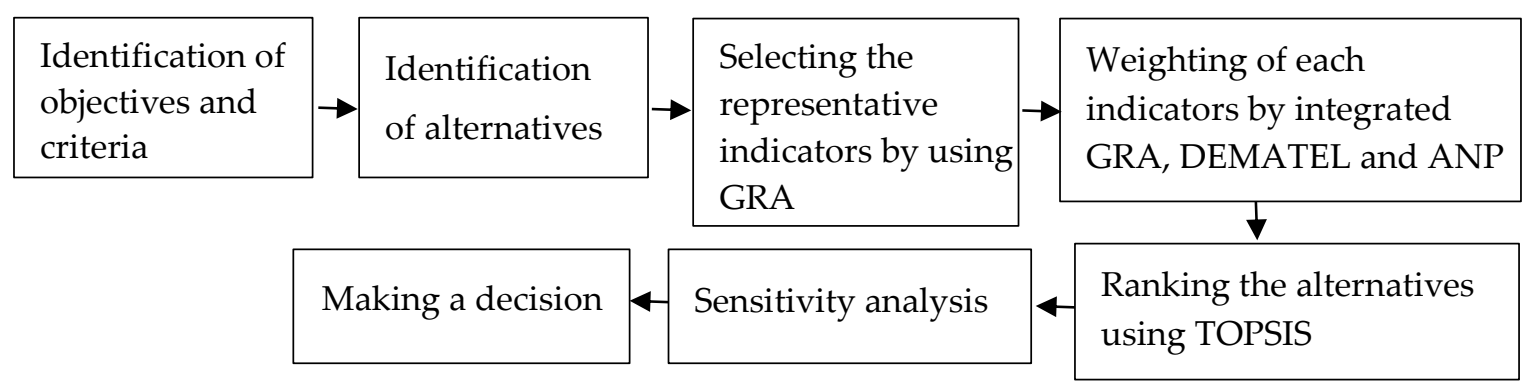

Figure 1. A summary of the hybrid multi-criteria decision-making (MCDM) model procedures.

\section{Literature Review}

\subsection{Previous Studies on the Company's Credit Evaluation}

Green credit refers to the financial institutions in the decision-making process of financing based on a consideration of potential environmental impacts. With the integration of environmental and ecological factors in the credit decision-making systems of banks by focusing on issues of environmental protection and ecology, companies produce high environmental and social benefits, thus supporting the long term development of banks' credit business.

In previous studies of banks' credit assessment of companies, many works have emphasized companies' financial operating performances as a basis for credit decision-making. In recent years, for example, Hsu [11] combined financial ratio variables and the risk-adjusted rate of return on capital (RAROC) as the evaluation criteria and developed a financial performance evaluation model. Bulgurcu [12] applied TOPSIS to evaluate the financial performance of firms in the Turkish automotive industry. Ghadikolaei and Esbouei [13] used the Fuzzy Analytic Hierarchy Process (FAHP), Fuzzy VIKOR, Fuzzy Additive Ratio Assessment (ARAS-F) and Fuzzy Complex Proportional Assessment (Fuzzy COPRAS) to establish a hierarchical financial performance evaluation model. Ghadikolaei et al. [14] conducted FANP and Fuzzy VIKOR rankings of companies based on their financial performance. Moghimi and Anvari [15] used FAHP and the TOPSIS method, along with data from their financial tables and the subsequent ranking of companies. Wang [16] integrated a grey relational analysis and Fuzzy TOPSIS to evaluate financial performance.

A study of green credit by Weber et al. [2] found that the sustainability of a company, as part of its financial performance, influences its creditworthiness. Sun and Wu [17] found that the green credit policy was as likely to increase economic growth as it was to do harm to it. Li [18] designed indicators of environmental credit assessment and built an AHP model for the environmental credit assessment of companies. $\mathrm{Xu}$ [19] constructed a Mamlquist green credit growth index to assess the comprehensive productivity performance of the banking and financial industry in China.

\subsection{The Application of Hybrid MCDM Methods}

A bank's green credit rating of companies is a multi-criteria decision-making problem. The main characteristics of a multi-criteria decision making model are the ability to evaluate multiple attributes, selections and rankings. Different multi-criteria decision making techniques have been developed, each with its own advantages and disadvantages [20]. In recent years, a hybrid MCDM model has been widely used in various fields. The most common hybrid MCDM model uses the VIKOR (TOPSIS) technique based on DEMATEL and ANP to solve the problem of conflicting criteria. As part of this hybrid model, the DEMATEL technique used a questionnaire survey as a tool of analysis, and investigated the relationships and strengths among assessment criteria. The DANP (DEMATEL-based ANP) method was used to determine the relative weights of the assessment criteria. Finally, VIKOR (TOPSIS) was used to obtain the final ranking of alternatives.

Recently, the hybrid MCDM model was successfully applied in the field of evaluation and selection. Büyüközkan and Çifçi [21] integrated fuzzy DEMATEL, fuzzy ANP and fuzzy TOPSIS to 
evaluate green suppliers. Ou Yang et al. [22] combined VIKOR, DEMATEL and ANP to evaluate the risk controls. Alimardani et al. [8] established a novel hybrid MCDM model including DEMATEL, ANP and TOPSIS for agile supply chains. Alam-Tabriz et al. [7] combined DEMATEL, ANP and TOPSIS to solve a supplier selection problem. Kuan and Chen [9] combined DEMATEL, ANP and VIKOR to evaluate the technological innovation capabilities of enterprises. Shen et al. [10] used DEMATEL, ANP and VIKOR for glamor stock selection.

Both the TOPSIS and VIKOR methods are suitable for solving decision making problems. However, TOPSIS is one of the most popular and well-known decision-making methods [23-25]. Therefore, this study combines the DEMATEL, ANP and TOPSIS methods for evaluating the green credit rating of companies.

\section{Methodology}

\subsection{Sample Selection}

In stakeholder theory, in order to achieve sustainable development objectives, enterprises need stakeholders' support and recognition. Therefore, enterprises should take the initiative to share the burden of social responsibility. The corporate social responsibility (CSR) is a combination of social responsibility and business strategy which can effectively enhance a company's future competitiveness and is also the source of the company's future competitiveness. Currently in Taiwan, the only media assessment mechanisms for corporate social responsibility are CommonWealth Magazine's "Corporate Citizenship Awards" and Global Views Monthly's "Corporate Social Responsibility Award". Among the winning companies, high-tech industry companies are the largest winners. However, the environmental impact of the high-tech electronics industry is not less than that of traditional industries. Moreover when it comes to the use of energy, resources, chemicals and heavy metals, the high-tech industry is worse. Therefore, this study examines green credit by researching the high-tech industry in Taiwan.

A CSR report gives the main, central idea of how a company can achieve sustainable development. This kind of report also mainstreams the nonfinancial performance information disclosure of companies worldwide. However, Taiwan's law does not require a company to publish a corporate social responsibility report and disclosure. Therefore, there are not many CSR reports in Taiwan [26]. This study uses the "Industrial Sustainable Development Clearinghouse" web site (https:/ / proj.ftis. org.tw/isdn/Report) to assess Taiwan's high-tech industry-listed companies that have voluntarily disclosed CSR reports as the research object. After excluding companies with incomplete data, we selected 55 of Taiwan's high-tech industry-listed companies in 2014 as the research sample.

\subsection{The Evaluation Criteria for Green Credit Policy}

For the purpose of providing a comprehensive assessment of the companies' green credit rating, this study covers financial and nonfinancial (such as credit risk, business growth, corporate social responsibility and environmental protection) performance assessment criteria and uses a triple bottom line (TBL) framework as the evaluation criteria. Therefore, as described below, this study selects companies' credit risk and economic, social and environmental performance criteria as the assessment criteria for green credit rating based on the previous literature and TBL. Thus, a framework was proposed for the identification of the evaluation criteria and for ranking the green credit of companies, as given in Figure 2. The description of the evaluation criteria are as follows.

\subsubsection{Credit Risk Evaluation Criteria}

The big three credit rating agencies are S\&P, Moody's and Fitch Ratings; in Taiwan, Taiwan Ratings and Taiwan Corporate Credit Risk Index (TCRI) provide credit ratings for financial institutions. Moreover, in Taiwan, the Taiwan Economic Journal reports on companies' overall risk assessment and offers a corporate credit risk indicator database. A company's credit risk is given a credit score 
from 1-10: the larger the number, the higher the level of credit risk. If the level is 10, it means that the company has closed down on risk. Based on the recommendations of previous studies [27-29], this study uses TCRI as a measure of companies' credit risks.

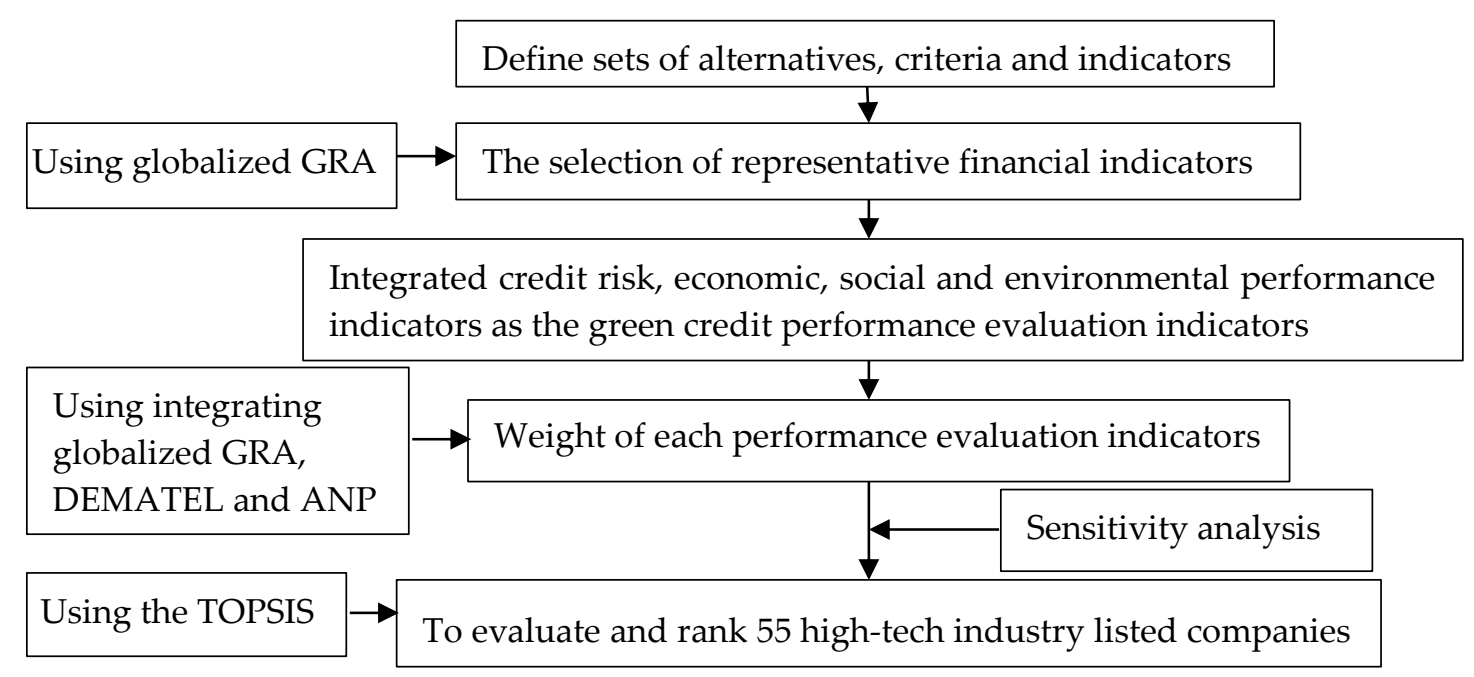

Figure 2. The framework to evaluate and rank the green credit of companies.

\subsubsection{Economic Performance Indicators}

The CEO of VanCity mentioned that when a corporation considers business strategy and corporate development, TBL should be defined as the financial, social and environmental performance [30]. However, though a company's economic performance includes its financial performance, in order to fully reflect the impact of business on the economy, many researchers [31-33] have suggested considering both the financial and nonfinancial performances. Therefore, in this study, economic performance is measured by using financial and nonfinancial performance indicators.

Different industries have different performance indicators. Based on a previous work [34], this study adopts financial ratios as financial performance evaluation indicators, which are grouped into three categories: operating ability, solvency and profitability, with 21 financial ratios. Operating ability includes the total asset turnover ratio, accounts receivable turnover, inventory turnover, fixed asset turnover, turnover of net worth, days-A/R turnover and days-inventory turnover. Solvency includes the cash flow adequacy ratio, cash reinvestment ratio, current ratio, quick ratio, long-term capital ratio, times interest earned, operation income/capital, and pretax income/capital. Profitability includes the return on assets, return on equity, profit margin, operating margin, net profit margin and earnings per share. The descriptions of the 21 financial indicators on the three categories are listed in Table 1.

We also consider nonfinancial performance measures, such as measures for risk and innovation capacity. In this study, we adopt risk measurement, including the degree of operating leverage (DOL), the degree of financial leverage (DFL) and RAROC, and the innovation capacity, including research and design $(R \& D)$ expenditure and total sales, as indicators to evaluate nonfinancial performance [11,35].

\subsubsection{Social Performance Indicators}

Sustainable development issues focus on the environmental component, but social factors and business stakeholders also apply moral pressure, forcing companies to pay more attention to the social dimension of sustainable development. Corporate social performance is a value of nonfinancial performance and is also considered as a part of the operating performance. Many researchers have attempted to investigate the link between corporate social performance and financial performance and have found a significant relationship between the two. Moreover, the social impact hypothesis, good management theory, and stakeholder contract costs theory also suggest that good corporate 
social performance may enhance companies' financial performances. That is, a good sustainability performance positively impacts a company's financial performance.

Table 1. Descriptions of the financial indicators on the three categories.

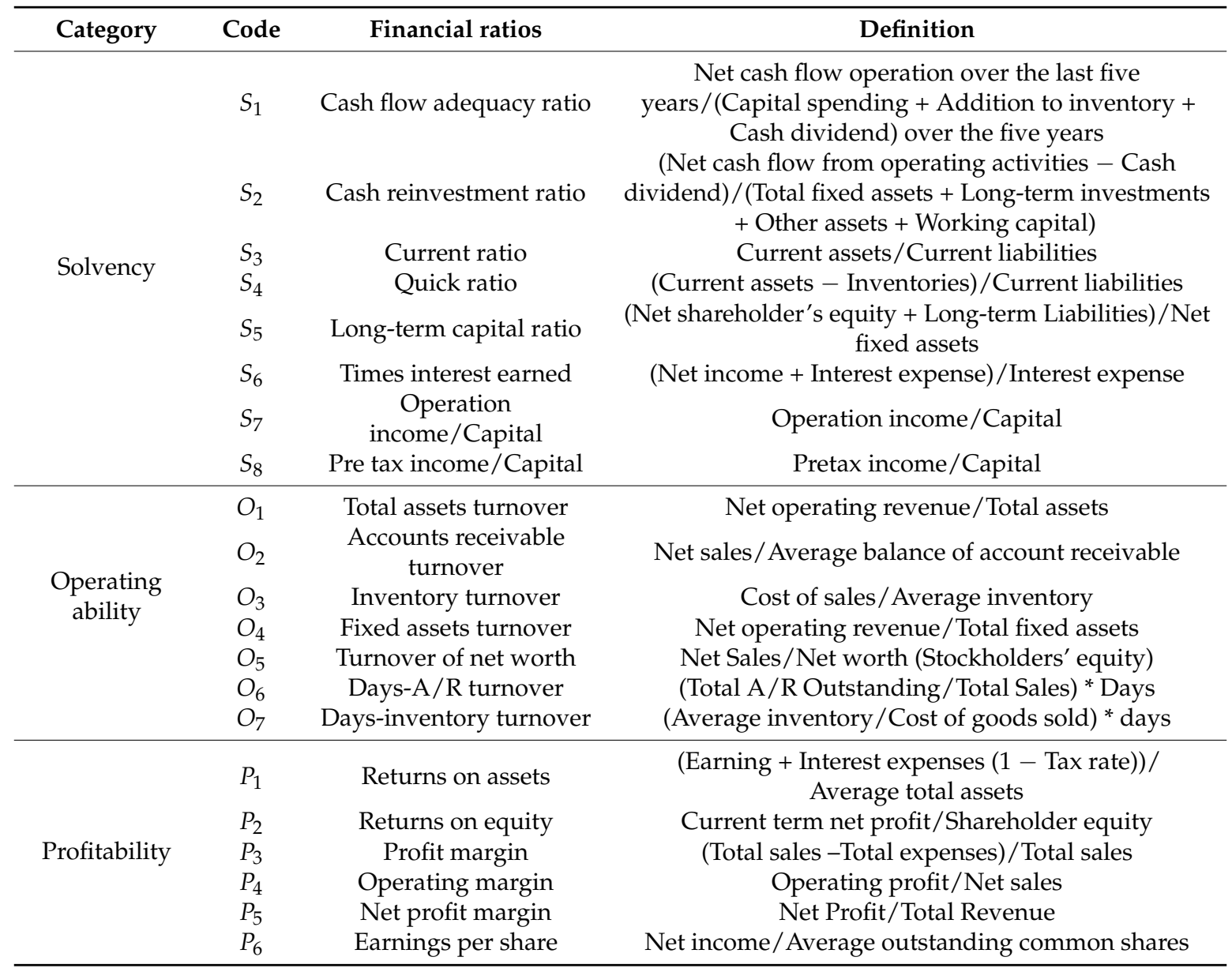

In the past, researchers have used various proxy measures to evaluate corporate social performance [36], such as the Fortune corporate reputation index, KLD (Kinder, Lydenberg and Domini Inc.) index and corporate social responsibility (CSR) ratings. However, the proxy measures of corporate social performance are mostly subjective and are based on qualitative data. In Taiwan, no such data regarding social performance is available. Therefore, the main constraint to carrying out research related to corporate social performance is the availability of data. Karagiorgos [37] mentioned that, in many studies, the measure of CSR is commonly referred to as the corporate social performance. Rundle-Thiele et al. [38] suggested that evaluating the corporate social performance would require the evaluation of CSR programs and policies. Fauzi et al. [39] mentioned that corporate social performance has the same meaning as CSR. Based on the finding of the abovementioned study, we use CSR to measure the corporate social performance.

The type of report is the main way to disclose nonfinancial performance information. Whether it is called sustainability reporting or CSR reporting, such a reporting is a key trend in global business development. The aim of CSR reporting is to disclose a company's environmental, economic and social performance. In the past, many studies have shown that social and environmental disclosures affect stakeholders [40]. Karagiorgos [37] applied a content analysis to CSR annual reports to measure CSR. Yllmaz [41] used CSR disclosures as a proxy measure indicator of social performance. Therefore, in this study, we adopt CSR disclosures as a proxy indicator to measure social performance. 


\subsubsection{Environmental Performance Indicators}

Porter [42] pointed out that environmental pressures encourage companies to face environmental issues, and the better the environmental performance of the company is, the higher the evaluation of future profitability of the investing public. Maxwell et al. [43] mentioned that companies can enhance corporate competitiveness by adopting a proactive environmental strategy to improve environmental performance [44].

Complete information on the environmental expenditure can illustrate a company's investment in environmental protection and rational allocation. King and Lenox [45] showed that less polluting companies may have better financial performance. López-Gamero et al. [46] also showed that by reducing the generation of pollution and increasing environmental expenditures, companies can improve their environmental performance, make more profits and achieve better financial performance. Wang et al. [47] analyzed the environmental expenditures of chemical industry companies to determine which ones had better financial performance and to test the relationship between environmental expenditures and firm performance. In other studies [47-51], environmental expenditures were used as a proxy for environmental protection. Therefore, we also adopted environmental expenditures as one of the indicators to measure corporate environmental performance.

Verrecchia [52] showed that good environmental performance by a company reduces future environmental costs, and this environmental information disclosure is good news to investors. Therefore, when a company has good environmental performance, it should disclose more environmental information. Environmental public information can help investors understand a company's concern for the environment. Under pressure from regulatory requirements, environmental information disclosure is an important part of business $[53,54]$. Therefore, this study uses environmental information disclosure as one of the indicators to measure corporate environmental performance.

In 1992, the World Business Council for Sustainable Development (WBCSD) described eco-efficiency (i.e., a win-win in both economic and ecological efficiency) as a business strategy for sustainable development. Thus, eco-efficiency has become a new environmental concept of sustainable development in the global industry and gradually attracted the attention of companies and governments. Eco-efficiency indicators are mainly used to assess companies' resource productivity performances, providing managers with a reference when making strategic decisions. Such indicators are also an important communication tool among company managers and other internal or external stakeholders. Therefore, this study uses eco-efficiency indicators to measure corporate environmental performance.

Eco-efficiency indicators are ratios of product or service value/environmental impact. This study uses four such indicators to measure environmental impact: energy consumption, water consumption, waste generation and emissions of greenhouse gases. Finally, we use the average eco-efficiency indicator as one of the proxies to measure corporate environmental performance.

\subsection{Data Source}

This study investigates traditional credit assessment criteria by adding environmental variables, CSR variables and risk variables as the measure of the green credit evaluation criteria. In order to verify the feasibility of the proposed hybrid MCDM model, we collected various evaluation indicator data. Among them, the data of 21 financial indicators, R\&D expenditures, DOL and DFL were taken from the Taiwan Economic Journal (TEJ) Data Bank. The TCRI data was provided by the Taiwan Corporate Credit Risk Index. The RAROC values were obtained from the VaR system of TEJ. The CSR reports are taken from the "Industrial Sustainable Development Clearinghouse" website. 


\subsection{The Proposed Hybrid MCDM Model}

This study proposes a quantitative evaluation model, which combines the GRA, DEMATEL, ANP and TOPSIS approaches to evaluate the green credit rating of companies. GRA is a kind of quantitative analysis used to evaluate the relative closeness to the ideal solution for each alternative. Based on the degree of similarity or dissimilarity between two alternatives used to measure the degree of proximity between the two alternatives, the closer the distance between the real object and ideal object is, the greater the degree of correlation. The DEMATEL method was mainly developed to solve scientific and human affair problems, to help better understand the world's problems and to obtain solutions. DEMATEL can effectively clarify the causal relationship and can reveal the relationships between various indicators. This method uses matrix calculation to obtain the casual relationships and to impact the strength. The ANP method uses pairwise comparisons to measure the mutual influence of each index system and specific indicators of weight. MCDM can help decision makers with a limited number of possible scenarios to evaluate and select a scenario consistent with ideal decision-making and to obtain a rank ordering of the possible options based on the characteristics of the various attributes of each scenario [55].

This study combines GRA, DEMATEL, ANP and TOPSIS to establish a comprehensive green credit decision model for quantifying data. The flowchart of the proposed framework is summarized in Figure 3. The operation steps are given as follows [27]:

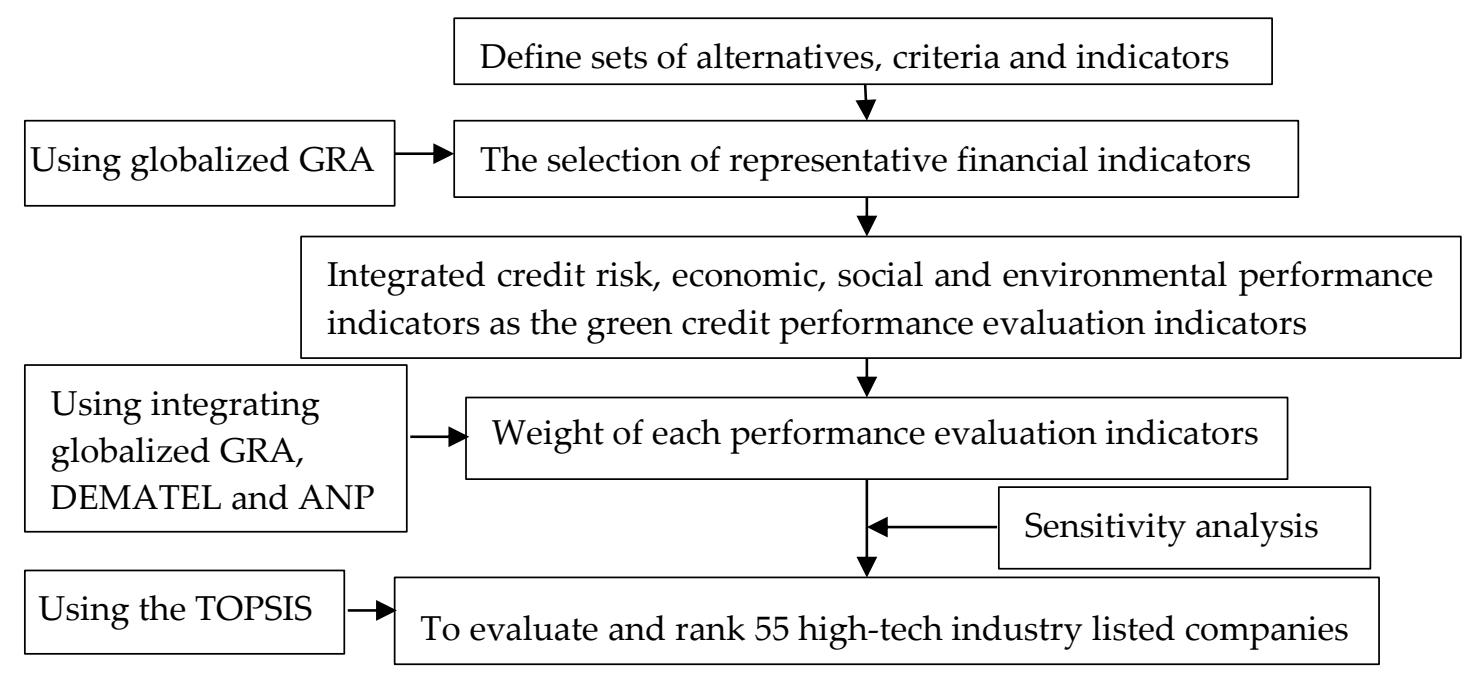

Figure 3. A flowchart of the proposed framework.

Step 1: Apply GRA to measure the degree of correlation between the indicators.

At the first step of the study, 21 financial ratios into three categories were chosen to be used as financial performance evaluation indicators. A financial performance evaluation with all 21 ratios makes calculations hard. Moreover, the correlation between the indicators in the group is high, selecting indicators that represent the characteristics of the group from each group helps to clarify the relationship between the indicators, and it is easier to evaluate the results. For the above reasons, it is important to reduce the financial ratios. The GRA is used to select the representative financial ratios for the three categories to measure the companies' financial performances [56]. The main reason for choosing the GRA is its computational flexibility, the small amount of data and the uncertainty of the distribution type of the data $[57,58]$. In the grey theory, there are two kinds of major of GRA, localized GRA and globalized GRA [59]. According to the suggestion in Wang [60], we used the globalized GRA to select the performance evaluation representative indicators (financial ratios). The globalized GRA procedure is described as follows:

1. Establish the original sequence $X_{i}=\left\{x_{1}(1), \ldots, x_{i}(k)\right\}$, where $i=1,2, \ldots, m k=1,2, \ldots, n$. 
2. Before attempting grey relational analysis, the original experimental data must be normalized. Normalization can be done according to whether the indicators are the larger-the-better, the smaller-the-better or the nominal-the-better criterion. In this step, all the representative financial ratios are normalized in the range between zero and one. There are methods of data normalization [61]:

(1) Larger-the-better: Upper-bound effectiveness measuring.

$$
x_{i}^{*}(k)=\frac{x_{i}(k)-\min \left[x_{i}(k)\right]}{\max \left[x_{i}(k)\right]-\min \left[x_{i}(k)\right]}
$$

where $\max \left[x_{i}(k)\right]$ is the maximum value of $x_{i}(k), \min \left[x_{i}(k)\right]$ is the minimum value of $x_{i}(k)$ and $x_{i}^{*}(k)$ is the value after grey relational generation.

(2) Smaller-the-better: Lower-bound effectiveness measuring

$$
x_{i}^{*}(k)=\frac{\max \left[x_{i}(k)\right]-x_{i}(k)}{\max \left[x_{i}(k)\right]-\min \left[x_{i}(k)\right]}
$$

(3) Nominal-the-better: Moderate effectiveness measuring

$$
x_{i}^{*}(k)=\frac{\left|x_{i}(k)-x_{o b}\right|}{\max \left[x_{i}(k)\right]-x_{o b}}
$$

where $x_{o b}$ is the objective value of $x_{i}(k)$. After the normalization of the data, we can obtain the normalized data matrix $D=\left[x_{i}^{*}(k)\right]_{m \times n}$.

3. Calculation of the grey relational coefficient For a sequence comparison, when any one sequence $x_{i}(k)$ can be used as a reference sequence, another sequence $x_{j}(k)$ acts as a comparative sequence. Then, the globalized grey relational coefficient is defined as

$$
\gamma\left(x_{i}(k), x_{j}(k)\right)=\frac{\Delta_{\min }+\varsigma \Delta_{\max }}{\Delta_{i j}(k)+\varsigma \Delta_{\max }}
$$

where $\Delta_{i j}(k)=\left|x_{i}(k)-x_{j}(k)\right|, \Delta_{\text {min }}=\min _{i} \min _{k}\left|x_{i}(k)-x_{j}(k)\right|, \Delta_{\max }=\max _{i} \max _{k}\left|x_{i}(k)-x_{j}(k)\right|$, $k=1,2, \cdots, n, i=1,2, \cdots, m, j \in k, \varsigma$ is the distinguishing coefficient and $\varsigma \in[0,1]$. In general, the distinguishing coefficient $\zeta$ is set as 0.5 [27].

4. Calculation of the grey relational grade The grey relational grade for a series of $X_{i}$ can be expressed as [62]

$$
\Gamma_{i j}=\Gamma\left(X_{i}, X_{j}\right)=\frac{1}{n} \sum_{k=1}^{n} \gamma\left(x_{i}(k), x_{j}(k)\right)
$$

5. Calculation of the grey relational matrix. Based on the grey relational grade, a grey relational matrix can be obtained,

$$
R_{m \times n}=\left[\begin{array}{cccc}
\Gamma_{11} & \Gamma_{12} & \cdots & \Gamma_{1 n} \\
\Gamma_{21} & \Gamma_{22} & \cdots & \Gamma_{2 n} \\
\vdots & \vdots & \ddots & \vdots \\
\Gamma_{m 1} & \Gamma_{m 2} & \cdots & \Gamma_{m n}
\end{array}\right]_{m \times n}
$$

where $\Gamma_{i j}$ represents the degree of correlation between $x_{i}(k)$ and $x_{j}(k)$ sequences.

Step 2: Use GRA-DEMATEL to investigate the relationships between indicators.

One of the purposes of this paper is to combine the GRA with DEMATEL to allow the DEMATEL method to be applied to the analysis of quantitative data. This study integrates credit risk evaluation, 
economic performance, social performance and environmental performance indicators and obtains the grey relational matrix by the globalized GRA procedure (Equations (1)-(6)) and then fits well into the concept of the DEMATEL method to obtain the GRA-DEMATEL procedure. The GRA-DEMATEL procedure can be summarized in the following steps:

1. Set up the initial direct-relation matrix.

Follow the basic concept of DEMATEL. When the degree of influence of the criteria is known, the factors associated with each other can be represented by a matrix, called the direct relation matrix $T$. Following the above concepts, this study uses the grey relational matrix (Equation (6)) instead of the direct-relation matrix in DEMATEL and uses the degree of the effect of criterion $i$ on criterion $j$. The diagonal element is set as 0 .

Each value of the matrix $T\left(\gamma_{i j}\right)$ represents the level of influence that criteria $i$ has on criteria $j$. Therefore,

$$
T=\left[\begin{array}{ccccc}
0 & \gamma_{12} & \gamma_{13} & \cdots & \gamma_{1 m} \\
\gamma_{21} & 0 & \gamma_{23} & \cdots & \gamma_{2 m} \\
\gamma_{31} & \gamma_{32} & 0 & \cdots & \gamma_{3 m} \\
\vdots & \vdots & \vdots & \ddots & \vdots \\
\gamma_{n 1} & \gamma_{n 2} & \gamma_{n 3} & \cdots & 0
\end{array}\right]
$$

2. Calculation of the normalized direct-relation matrix

Calculate the normalized initial direct-relation matrix $X$, by $X=\lambda \cdot T$, where

$$
\lambda=\frac{1}{\max _{1 \leq i \leq m}\left(\sum_{j=1}^{m} \gamma_{i j}\right)}
$$

3. Calculation of the total-relation matrix

Because $\lim _{k \rightarrow \infty} X^{k}=O, O$ is a zero matrix, we can derive the total-relation matrix $Z$ as

$$
Z=\lim _{k \rightarrow \infty}\left(X+X^{2}+\cdots+X^{k}\right)=X(I-X)^{-1}
$$

where $I$ is the identity matrix.

Step 3: Construct the supermatrix of the DANP [63].

Here, we use the GRA-DEMATEL combined with the ANP to determine the weights of the indicators. Apply the total-relation matrix of GRA-DEMATEL in the supermatrix of ANP. By Equation (11), we can obtain the total-relation matrix $Z$,

$$
Z=\left[\begin{array}{ccccc}
t_{11} & \cdots & t_{1 j} & \cdots & t_{1 m} \\
\vdots & & \vdots & & \vdots \\
t_{i 1} & \cdots & t_{i j} & \cdots & t_{i m} \\
\vdots & & \vdots & & \vdots \\
t_{n 1} & \cdots & t_{n j} & \cdots & t_{n m}
\end{array}\right]
$$

After normalizing the matrix $Z$, we obtain the normalization matrix $Z_{s}$,

$$
Z_{s}=\left[\begin{array}{ccccc}
t_{11} / d_{1} & \cdots & t_{1 j} / d_{1} & \cdots & t_{1 m} / d_{1} \\
\vdots & & \vdots & & \vdots \\
t_{i 1} / d_{i} & \cdots & t_{i j} / d_{i} & \cdots & t_{i m} / d_{i} \\
\vdots & & \vdots & & \vdots \\
t_{n 1} / d_{n} & \cdots & t_{n j} / d_{n} & \cdots & t_{n m} / d_{n}
\end{array}\right]=\left[\begin{array}{ccccc}
t_{11}^{s} & \cdots & t_{1 j}^{s} & \cdots & t_{1 m}^{s} \\
\vdots & & \vdots & & \vdots \\
t_{i 1}^{s} & \cdots & t_{i j}^{s} & \cdots & t_{i m}^{s} \\
\vdots & & \vdots & & \vdots \\
t_{n 1}^{s} & \cdots & t_{n j}^{s} & \cdots & t_{n m}^{s}
\end{array}\right]
$$


where $d_{i}=\sum_{j=1}^{m} t_{i j}$.

By transposing the normalization matrix, we can obtain supermatrix $W$,

$$
W=\left(Z_{s}^{\prime}\right)=\left[\begin{array}{ccccc}
t_{11}^{s} & \cdots & t_{i 1}^{s} & \cdots & t_{n 1}^{s} \\
\vdots & & \vdots & & \vdots \\
t_{1 j}^{s} & \cdots & t_{i j}^{s} & \cdots & t_{n j}^{s} \\
\vdots & & \vdots & & \vdots \\
t_{1 m}^{s} & \cdots & t_{i m}^{s} & \cdots & t_{n m}^{s}
\end{array}\right]=\left[\begin{array}{ccccc}
w_{11} & \cdots & w_{i 1} & \cdots & w_{n 1} \\
\vdots & & \vdots & & \vdots \\
w_{1 j} & \cdots & w_{i j} & \cdots & w_{n j} \\
\vdots & & \vdots & & \vdots \\
w_{1 m} & \cdots & w_{i m} & \cdots & w_{n m}
\end{array}\right]
$$

Step 4: Calculate the weighted supermatrix

The weighted supermatrix can be obtained as follows:

$$
W_{w}=\left[\begin{array}{ccccc}
t_{11}^{s} \times w_{11} & \cdots & t_{1 j}^{s} \times w_{i 1} & \cdots & t_{1 m}^{s} \times w_{n 1} \\
\vdots & & \vdots & & \vdots \\
t_{i 1}^{s} \times w_{1 j} & \cdots & t_{i j}^{s} \times w_{i j} & \cdots & t_{i m}^{s} \times w_{n j} \\
\vdots & & \vdots & & \vdots \\
t_{n 1}^{s} \times w_{1 m} & \cdots & t_{n j}^{s} \times w_{i m} & \cdots & t_{n m}^{s} \times w_{n m}
\end{array}\right] .
$$

Step 5: Determine the weights of evaluation criteria.

Use the ANP method to obtain the limit supermatrix, $\lim W_{w}^{k}$, until the supermatrix has converged and becomes a long-term stable supermatrix. This stable convergence value is the relative weight of the evaluation criteria.

Step 6: Establish a normalized evaluation matrix based on the TOPSIS method.

After the weights of the indicators were determined using the GRA-DEMATEL combined with the ANP, the TOPSIS was used to evaluate and rank the company's green credit performance.

If a decision matrix is made for a set of $\mathrm{n}$ criteria and $\mathrm{m}$ alternatives, then the normalized value $r_{i j}$ is calculated by using Equations (1)-(3), where $i=1,2, \cdots, m, j=1,2, \cdots, n$ and $r_{i j}$ is the $i$ th attribute in the $j$ th evaluation attribute of the normalized value.

Step 7: Construct the weighted normalized decision matrix.

The weighted normalized decision matrix is calculated as

$$
v_{i j}=w_{i} \times r_{i j}
$$

where $w_{i}$ represents the weight of the $i$ th criterion and the data obtained from Step 5.

Step 8: Determine the positive ideal $\left(A^{+}\right)$and negative-ideal $\left(A^{-}\right)$solutions.

Determine the positive ideal solution and negative-ideal solution, respectively:

$$
\begin{aligned}
& A^{+}=\left\{v_{1}^{+}, v_{2}^{+}, \ldots, v_{n}^{+}\right\}=\left\{\left(\max _{i} \quad v_{i j} \mid j \in B\right),\left(\min _{i} \quad v_{i j} \mid j \in C\right) \mid i=1,2, \ldots, m\right\} \\
& A^{-}=\left\{v_{1}^{-}, v_{2}^{-}, \ldots, v_{n}^{-}\right\}=\left\{\left(\min _{i} \quad v_{i j} \mid j \in B\right),\left(\max _{i} \quad v_{i j} \mid j \in C\right) \mid i=1,2, \ldots, m\right\}
\end{aligned}
$$

where $B$ is the set of benefit type attributes and $C$ is the set of cost type attributes.

Step 9: Calculate the separation measures using the m-dimensional Euclidean distance.

To measure the distance of each alternative, use the positive ideal solution and the negative ideal solution, respectively:

$$
s_{i}^{+}=\sqrt{\sum_{j=1}^{n}\left(v_{i j}-v_{j}^{+}\right)^{2}}, i=1,2, \ldots, m
$$




$$
s_{i}^{-}=\sqrt{\sum_{j=1}^{n}\left(v_{i j}-v_{j}^{-}\right)^{2}}, i=1,2, \ldots, m
$$

Step 10: Calculate the relative closeness to the ideal solution and rank the alternatives.

We compute the relative closeness coefficient $\left(C_{i}^{*}\right)$ of each alternative with respect to the positive ideal solution, as defined below:

$$
C_{i}^{*}=\frac{S_{i}^{-}}{S_{i}^{-}+S_{i}^{+}}
$$

where $0 \leq C_{i}^{*} \leq 1$ and the larger the coefficient value, the better the performance of the alternatives.

\subsection{Sensitivity Analysis}

The purpose of a sensitivity analysis is mainly to examine whether the data have a significant impact on the results. Using a weight sensitivity analysis, Moghassem and Fallahpour [64] and Moghassem [65] showed whether all the weights of the criteria, 5\%, 10\%, $15 \%$ and $20 \%$, tend to increase or decrease by repeating the TOPSIS approach. Other studies have shown that weight has great effects on the results of TOPSIS [66]. Therefore, based on the findings of Moghassem and Fallahpour [64] and Moghassem [65], this study performs a weight sensitivity analysis.

\section{Empirical Results}

\subsection{The Results of Banks' Green Credit Decision-Making}

In order to analyze the banks' green credit decisions, this study uses economic (21 financial indicators and R\&D expenditure), social (CSR disclosure), environmental (eco-efficiency indicators, environmental expenditure and environmental information disclosure) and credit risk (TCRI, RAROC, DOL and DFL) as the bank's evaluation criteria to measure the companies' green credit. Firstly, a globalized GRA was used to select the representative indicators of financial performance among the 21 financial indicators. Then, the representative financial, social, environmental and credit risks indicators were integrated to establish the decision matrix. Using the integrated globalized GRA-DEMATEL method, we can determine the degree of influence of each evaluation indicator. Then, a globalized GRA-DEMATEL with ANP was adopted to determine the relative weight of each evaluation indicator. Finally, a globalized GRA-DEMATEL-ANP with the TOPSIS method was applied for the evaluation and ranking of the 55 high-tech industry-listed companies in Taiwan. By using a sensitivity analysis, we can understand the impact of the weight change on the performance rankings. The detailed calculation procedure is described in Appendix B.

\subsubsection{The Selection of Representative Financial Indicators}

This study uses financial ratios which are among the most popular and widely used in financial statement analyses. The selected ratios can be divided into three categories: profitability (6 indicators), operating ability (7 indicators) and solvency ( 8 indicators), as a measure of a company's financial performance criteria. However, a high correlation exists between financial indicators within each category. Thus, following the performance score method proposed by Feng and Wang [67], we apply a globalized GRA with category characteristics to select representative financial indicators from each category, as a measure of financial performance.

First, in order to make the initial sequence data comparable, based on the characteristics of evaluation indicators, we normalized the financial indicators using Equations (1)-(3). Among the 21 financial indicators, the $O_{6}$ (days-A/R turnover) and $O_{7}$ (days-inventory turnover) variables have the following characteristics: the smaller-the-better. The rest of the variables are the larger-the-better. Then, substituting the data obtained from normalization into Equations (4)-(6), we can obtain the three categories, profitability, operating ability and solvency, of the grey relational matrix, as shown in Table A2 in Appendix B. By setting the threshold value at 0.7 [34], we can calculate the performance 
score for each evaluation indicator. For the profitability category, we selected three indicators, including $P_{1}$ (return on assets), $P_{2}$ (return of equity) and $P_{5}$ (net profit margin). For the operating ability category, we selected two indicators, $O_{5}$ (turnover of net worth) and $O_{7}$ (days-inventory turnover). Finally, in the solvency category, we selected the following four indicators: $S_{3}$ (current ratio), $S_{5}$ (long-term capital ratio), $S_{6}$ (times interest earned) and $S_{7}$ (oper. income/capital).

4.1.2. Integrating Globalized GRA and DEMATEL to Calculate the Degree of the Relationship between Two Indicators

This study uses a globalized GRA to obtain the degree of correlation between two evaluation indicators and to establish a direct-relation matrix. Using a combination of nine representative financial indicators, R\&D expenditure, CSR discourse, eco-efficiency indicators, environmental expenses, environmental information discourse, TCRI, RAROC, DOL and DFL, we have a total of 18 evaluation indicators. All the above indicators are summarized in Table 2. Among them, $\mathrm{O}_{7}$, TCRI, DOL and DFL have the following characteristics: the smaller-the-better. Therefore, based on Equations (1)-(3), the raw data can be normalized to the range of 0 and 1. Then, through Equations (4)-(6), we can obtain the grey relational matrix and the diagonal value is set to 0 to establish a direct-relation matrix $T$. Using the DEMATEL method, the total-relation matrix $Z$ can be obtained by Equations (7)-(10), as seen in Appendix B.

Table 2. The selected indicators for banks in green credit decision-making.

\begin{tabular}{cc}
\hline Criteria & Indicators \\
\hline Credit risk & Taiwan Corporate Credit Risk Index (TCRI) \\
\hline Economic performance & $\begin{array}{r}\text { Return on assets }\left(P_{1}\right) \text {, Return of equity }\left(P_{2}\right) \text { and Net profit margin } \\
\left(P_{5}\right), \text { Turnover of net worth }\left(O_{5}\right) \text {, Days-inventory turnover }\left(O_{7}\right), \\
\text { Current ratio }\left(S_{3}\right), \text { Long-term capital ratio }\left(S_{5}\right), \text { Times interest earned } \\
\left(S_{6}\right), \text { Oper. income/capital }\left(S_{7}\right), \text { R\&D expenditure (RDE), } \\
\text { Risk-adjusted rate of return on capital (RAROC), Degree of } \\
\text { operating leverage (DOL) and Degree of financial leverage (DFL) }\end{array}$ \\
\hline Social performance & Corporate social responsibility disclosure (CSRD) \\
\hline Environmental performance & Eco-efficiency indicators (ECO), Environmental expenditure (EE) \\
& and Environmental information disclosure (EID)
\end{tabular}

4.1.3. Integrating Globalized GRA-DEMATEL and ANP to Calculate the Weights of Evaluation Indicators

From the results of the total-relation matrix, we can obtain the degree of influence between two evaluation indicators. Then, we use the software "Super Decision 2.2" to directly input the resulting data so as to compare the degree of influence of indicators mapped by the integration of a globalized GRA and the DEMATEL method (Equation (20)). By using the Super Decision package, the weighted supermatrix $\left(W_{W}\right)$ was calculated, which is a $18 \times 18$ matrix, as seen in Appendix B.

We can obtain the limited supermatrix by multiplying the weighted supermatrix by itself multiple times. When the supermatrix results in a fixed convergence of the extreme values, the relative weight for each indicator can be obtained. The results are presented in Table A3 in Appendix B.

\subsubsection{Using the TOPSIS Method to Evaluate and Rank High-Tech Industry Listed Companies}

Through Steps 6 to 10, we can obtain the green credit performance and ranking of the 55 high-tech industry-listed companies in Taiwan. First, we establish the evaluation matrix based on the 18 evaluation indicators. Then, the raw data can be normalized based on Equations. (1)-(3). We can obtain the normalized decision matrix $R$, which is a $55 \times 18$ matrix, as seen in Appendix B.

In this study, we integrated a globalized GRA, DEMATEL and the ANP method to obtain the weights of 18 evaluation indicators. The results are shown in Table 3. Then, in accordance with Step 7, 
substituting the weights of 18 evaluation indicators into Equation (14), we can obtain the weighted normalized decision matrix $V$, as seen in Appendix $\mathrm{B}$.

Through Step 8 (Equation (15) and (16)), we can obtain the positive idea solution and the negative idea solution. Finally, applying Equations (17)-(19), we can obtain the distance $\left(S_{i}^{+}\right.$and $\left.S_{i}^{-}\right)$and relative closeness coefficient $\left(C_{i}^{*}\right)$ of each company. Then, we rank the 55 high-tech industry-listed companies based on the value of $C_{i}^{*}$. A larger value of $C_{i}^{*}$ represents a more superior company. The results are presented in Table 3.

The results of Table 3 show that, among the 55 high-tech industry-listed companies in Taiwan in 2014, the value of $C_{i}^{*}$ for company F14 is 0.52285 , which is the highest value. That is, company F14 had the best green credit evaluation performance. The empirical results also show that the value of $C_{i}^{*}$ for company F34 is 0.37513 , which is the lowest value among the 55 listed companies, representing the worst green credit evaluation performance. As seen in Table 3, the more front rankings of the companies, the better the green credit evaluation performance is; this shows that, among the business activities of companies, its impact on the environment and social issue is relatively low. When financial institutions and banks offer green credit loan to companies, they can give a lower interest rate. Conversely, if a company has a low ranking, when financial institutions and banks offer green credit loans to the company, they can give a higher interest rate.

Table 3. The final distance measures, relative closeness coefficients and rankings.

\begin{tabular}{|c|c|c|c|c|c|c|c|c|c|}
\hline Companies & $\overline{S_{i}^{+}}$ & $\overline{S_{i}^{-}}$ & $\overline{C_{i}}$ & Rank & Companies & $S_{i}^{+}$ & $\overline{S_{i}^{-}}$ & $\overline{C_{i}}$ & Rank \\
\hline F1 & 0.16577 & 0.10763 & 0.39367 & 52 & F29 & 0.14519 & 0.13226 & 0.47671 & 15 \\
\hline F2 & 0.15567 & 0.11922 & 0.43370 & 34 & F30 & 0.15546 & 0.12591 & 0.44749 & 26 \\
\hline F3 & 0.14356 & 0.13242 & 0.47982 & 10 & F31 & 0.15034 & 0.13523 & 0.47355 & 17 \\
\hline F4 & 0.13650 & 0.14453 & 0.51429 & 3 & F32 & 0.15342 & 0.12923 & 0.45720 & 21 \\
\hline F5 & 0.14406 & 0.13166 & 0.47753 & 14 & F33 & 0.16088 & 0.10984 & 0.40573 & 48 \\
\hline F6 & 0.16029 & 0.11685 & 0.42163 & 43 & F34 & 0.17682 & 0.10615 & 0.37513 & 55 \\
\hline F7 & 0.15130 & 0.12547 & 0.45333 & 23 & F35 & 0.15611 & 0.11558 & 0.42542 & 42 \\
\hline F8 & 0.14240 & 0.12854 & 0.47441 & 16 & F36 & 0.14905 & 0.13079 & 0.46737 & 19 \\
\hline F9 & 0.14303 & 0.13288 & 0.48162 & 9 & F37 & 0.15046 & 0.12175 & 0.44727 & 27 \\
\hline F10 & 0.14431 & 0.13589 & 0.48498 & 7 & F38 & 0.14867 & 0.13627 & 0.47824 & 13 \\
\hline F11 & 0.14409 & 0.13211 & 0.47830 & 12 & F39 & 0.15173 & 0.12381 & 0.44934 & 25 \\
\hline F12 & 0.15667 & 0.11915 & 0.43199 & 36 & F40 & 0.15878 & 0.11763 & 0.42556 & 41 \\
\hline F13 & 0.16713 & 0.10893 & 0.39458 & 51 & F41 & 0.14057 & 0.13590 & 0.49155 & 5 \\
\hline F14 & 0.14394 & 0.15773 & 0.52285 & 1 & F42 & 0.17360 & 0.11934 & 0.40738 & 46 \\
\hline F15 & 0.15411 & 0.13074 & 0.45897 & 20 & F43 & 0.16653 & 0.10978 & 0.39732 & 50 \\
\hline F16 & 0.14373 & 0.13678 & 0.48763 & 6 & F44 & 0.16157 & 0.11690 & 0.41978 & 44 \\
\hline F17 & 0.15881 & 0.11244 & 0.41452 & 45 & F45 & 0.15488 & 0.11921 & 0.43493 & 33 \\
\hline F18 & 0.15127 & 0.11791 & 0.43802 & 31 & F46 & 0.15779 & 0.11713 & 0.42605 & 40 \\
\hline F19 & 0.16577 & 0.10763 & 0.39367 & 35 & F47 & 0.14519 & 0.13598 & 0.48361 & 8 \\
\hline F20 & 0.15567 & 0.11922 & 0.43370 & 22 & F48 & 0.17064 & 0.10381 & 0.37825 & 54 \\
\hline F21 & 0.14356 & 0.13242 & 0.47982 & 11 & F49 & 0.16161 & 0.12268 & 0.43153 & 37 \\
\hline F22 & 0.13650 & 0.14453 & 0.51429 & 18 & F50 & 0.16004 & 0.11966 & 0.42782 & 38 \\
\hline F23 & 0.14406 & 0.13166 & 0.47753 & 32 & F51 & 0.16281 & 0.11144 & 0.40635 & 47 \\
\hline F24 & 0.16029 & 0.11685 & 0.42163 & 28 & F52 & 0.15049 & 0.12294 & 0.44963 & 24 \\
\hline F25 & 0.15130 & 0.12547 & 0.45333 & 2 & F53 & 0.16963 & 0.10966 & 0.39265 & 53 \\
\hline F26 & 0.14240 & 0.12854 & 0.47441 & 4 & F54 & 0.16421 & 0.12275 & 0.42776 & 39 \\
\hline F27 & 0.14303 & 0.13288 & 0.48162 & 29 & F55 & 0.17838 & 0.12123 & 0.40464 & 49 \\
\hline F28 & 0.14431 & 0.13589 & 0.48498 & 30 & & & & & \\
\hline
\end{tabular}

\subsection{The Results of Sensitivity Analysis}

Weight is an important factor when using the TOPSIS method to rank alternatives. In order to verify the weight stability of the proposed integrative globalized GAR-DEMATEL-ANP-TOPSIS process, Based on the sensitivity analysis described in Section 3.3, in this study, the weights are increased or decreased by 5\%,10\%,15\% and 20\%. The results are shown in Table A4 in Appendix C. By substituting the results of the weight (Table A4) in the TOPSIS method (Equations (14)-(19)), we can 
calculate the 55 companies' ranking results using a sensitivity analysis, as shown in Table A5 in Appendix C.

Ballı and Korukoğlu [68] and Chakraborty et al. [69] suggested using both the Spearman and Kendall tau correlation tests to examine the correlation of two rankings (the results of Tables 3 and A5). The calculated results show that the Spearman correlations and the Kendall coefficient were 0.981 and 0.9 , respectively. The results indicate a strong positive relationship between the two rankings. That is, the evaluation results changed little when the value of weighting was adjusted, and therefore, the proposed weighting method offers stability. Thus, applying the proposed hybrid MCDM analytical procedure to the analysis of banks' green credit evaluation decisions is feasible.

\section{Conclusions and Future Work}

The era of putting too much emphasis on economic development has passed. In the current era of the green revolution, sustainable development has already become a key issue worldwide. Green credit is expected to consciously guide the flow of funds through financial institutions, to reduce the levels of environmental pollution, to protect the ecological balance, to facilitate the conservation of natural resources and to serve as effective mechanisms for the sustainable development of communities.

Traditionally, credit assets (whether investment or credit) are the main source of profit for banks. However, within a bank's current credit risk evaluation framework, companies' risks due to changing climates and related environmental problems are not included in the evaluation process. The presence of loopholes in risk identification is not conducive to a bank's sustainable management and development. Therefore, in order to plug the loopholes in risk identification, this study combines credit risk and economic, environmental and social performance evaluation criteria within banks' green credit evaluation criteria. This study proposes a combination of globalized GRA, DEMATEL, ANP and the TOPSIS procedure. The proposed procedure is applied using quantitative data in a hybrid MCDM model, thereby establishing a suitable green credit rating mechanism for banks. Moreover, the 55 listed high-tech companies in Taiwan are taken as the evaluation objects to verify the applicability of the green credit rating mechanism. Finally, a weight sensitivity analysis was used to test the stability in this study. The government can use the results as a reference for promoting future green finance reform.

The empirical results of this study show that, under an integrated environment, taking into account corporate social responsibility and credit risk evaluation criteria, companies F14, F25 and F4 are the top three green credit performers in Taiwan's high-tech industry. Banks and financial institutions should give lower interest rates on credit funds to support these low power, low-pollution companies. The worst three are ranked as follows: F53, F48 and F34. Through high interest rates, banks and financial institutions can limit the financing of high pollution and high energy consumption companies. The results of a weight sensitivity analysis show that the proposed hybrid MCDM model offers stability.

In terms of practical meaning, through the publication of this study, we can help Taiwan's banking industry establish a set of green credit evaluation criteria for quantitative data as a reference for future loans to businesses. The results of the green credit assessment of enterprises in the same industry are conducive to the development of green credit in the banking industry. The higher the green credit rating, the lower the interest on loans is and the higher the priority loans given to companies are. Conversely, a lower-ranking company gives a lower amount of loans or no loans. For investors, in addition to paying attention to the company's financial information, we should pay more attention to nonfinancial investment information. The empirical results will enable investors to better understand the performance of the company's sustainable development and to provide investors with more forward-looking information on the company's operational performance, which can be a more complete assessment of the company's real operating conditions. The assessment results can also serve as a reference for the government to promote green finance and to assist the green energy technology industry to obtain medium and long-term funds. In the academic sense, the previous literatures show that the DEMATEL method is used for the analysis of qualitative data. However, the combination of 
GRA and DEMATEL can be applied to the analysis of quantitative data. The proposed modified hybrid MCDM model can also be applied to the evaluation and ranking of quantitative data for green credit.

In terms of research restrictions, because the green credit of Taiwan's banking industry is still in its infancy, it is impossible to know the credit criteria adopted, and this paper is a quantitative study and does not include types of variables in questionnaires, so it cannot include all the evaluation indicators proposed by previous literatures. Furthermore, because Taiwanese companies have not fully disclosed their CSR reports, they are unable to conduct green credit assessments for all companies in the same industry.

In recent years, the green credit has been become an international trend. However, in Taiwan, this kind of credit is still in its infancy. Thus, data related to environmental variables, CSR variables and credit risk variables, which can affect green credit performances, are not available. In the future, by adding more variables to the proposed decision analysis process, researchers can make the green credit rating decision-making process more credible. Apart from the high-tech industry, the proposed hybrid MCDM model can also be used in other industries such as manufacturing, biotechnology and pharmaceuticals.

Author Contributions: C.-C.Y., S.-L.O. and L.-C.H. conceived, designed, and wrote together this article. Conceptualization, L.-C.H.; Methodology, S.-L.O. and L.-C.H.; Software, C.-C.Y. and S.-L.O.; Writing-Original Draft Preparation, C.-C.Y., S.-L.O. and L.-C.H.; Writing-Review \& Editing, C.-C.Y., S.-L.O. and L.-C.H.

Funding: The authors would like to thank the National Science Council of the Republic of China, Taiwan for financially supporting this research under Contract No. MOST 104-2410-H-275-005.

Conflicts of Interest: The authors declare no conflict of interest.

\section{Appendix A. List of Equator Principles}

In the June 2013 version of the third version of the Equator Principles, there are 10 Equator Principles that are shown in Table A1.

Table A1. A list of Equator Principles.

\begin{tabular}{|c|c|c|}
\hline Principle & Statement of Principles & Main Contents \\
\hline Principle 1 & Review and Categorisation & $\begin{array}{l}\text { When a project is proposed for financing, it is reviewed and classified according to } \\
\text { the magnitude of its potential environmental and social risks and impacts. }\end{array}$ \\
\hline Principle 2 & $\begin{array}{l}\text { Environmental and Social } \\
\text { Assessment }\end{array}$ & $\begin{array}{l}\text { For all projects, the relevant environmental and social risks and impacts of the } \\
\text { proposed project }\end{array}$ \\
\hline Principle 3 & $\begin{array}{l}\text { Applicable Environmental and } \\
\text { Social Standards }\end{array}$ & $\begin{array}{l}\text { The assessment process should address compliance with the relevant host country } \\
\text { laws, regulations and permits that pertain to environmental and social issues. }\end{array}$ \\
\hline Principle 4 & $\begin{array}{l}\text { Environmental and Social } \\
\text { Management System and } \\
\text { Equator Principles Action Plan }\end{array}$ & $\begin{array}{l}\text { An Environmental and Social Management System (ESMS) must be developed or } \\
\text { maintained by the client. }\end{array}$ \\
\hline Principle 5 & Stakeholder Engagement & $\begin{array}{c}\text { The client requires a demonstration of effective stakeholder engagement as an } \\
\text { ongoing process in a structured and culturally appropriate manner with } \\
\text { affected communities. }\end{array}$ \\
\hline Principle 6 & Grievance Mechanism & $\begin{array}{l}\text { The client requires the establishment of a grievance mechanism designed to receive } \\
\text { and facilitate the resolution of concerns and grievances. }\end{array}$ \\
\hline Principle 7 & Independent Review & $\begin{array}{l}\text { For all projects, an independent consultant, not directly associated with the client, } \\
\text { will carry out an Independent Review of the assessment documentation. }\end{array}$ \\
\hline Principle 8 & Covenants & $\begin{array}{l}\text { For all projects, the client will covenant in the financing documentation a compliance } \\
\text { with all relevant host country environmental and social laws, regulations and } \\
\text { permits in all material respects. }\end{array}$ \\
\hline Principle 9 & $\begin{array}{l}\text { Independent Monitoring } \\
\text { and Reporting }\end{array}$ & $\begin{array}{l}\text { To assess the project compliance with the Equator Principles and to ensure ongoing } \\
\text { monitoring and reporting after Financial Closure and over the life of the loan. }\end{array}$ \\
\hline Principle 10 & Reporting and Transparency & $\begin{array}{c}\text { The Equator Principles Financial Institutions (EPFI) will report publicly on } \\
\text { transactions that have reached financial closure and on its Equator Principles } \\
\text { implementation processes and experience, taking into account appropriate } \\
\text { confidentiality considerations. }\end{array}$ \\
\hline
\end{tabular}

Source: https:/ / equator-principles.com/wp-content/uploads/2017/03/equator_principles_III.pdf. 


\section{Appendix B. Results in Detail}

This study proposed a hybrid MCDM model that integrated globalized GRA, DEMATEL, ANP and TOPSIS to assess banks' green credit decision analysis. The procedure is as follows:

1. As mentioned in Section 4, we collected 21 financial indicators by using a globalized GRA to obtain the grey relational matrix, as shown in Table A2. According to Reference [34], we selected 9 indicators (see Section 4.1).

Table A2. The grey relational matrix.

\begin{tabular}{|c|c|c|c|c|c|c|c|c|}
\hline \multicolumn{9}{|c|}{ Profitability } \\
\hline & $P_{1}$ & $P_{2}$ & $P_{3}$ & $P_{4}$ & $P_{5}$ & $P_{6}$ & & \\
\hline$P_{1}$ & 1 & 0.6261 & 0.6432 & 0.8573 & 0.8492 & 0.7821 & & \\
\hline$P_{2}$ & 0.6931 & 1 & 0.5954 & 0.6618 & 0.6559 & 0.6644 & & \\
\hline$P_{3}$ & 0.7083 & 0.5954 & 1 & 0.7511 & 0.7574 & 0.7391 & & \\
\hline$P_{4}$ & 0.8624 & 0.6020 & 0.7010 & 1 & 0.9384 & 0.7997 & & \\
\hline$P_{5}$ & 0.8578 & 0.6029 & 0.7136 & 0.9399 & 1 & 0.7981 & & \\
\hline$P_{6}$ & 0.8099 & 0.6403 & 0.7192 & 0.8208 & 0.8154 & 1 & & \\
\hline \multicolumn{9}{|c|}{ Operating ability } \\
\hline & $O_{1}$ & $\mathrm{O}_{2}$ & $\mathrm{O}_{3}$ & $\mathrm{O}_{4}$ & $\mathrm{O}_{5}$ & $\mathrm{O}_{6}$ & $\mathrm{O}_{7}$ & \\
\hline$O_{1}$ & 1 & 0.732 & 0.7762 & 0.7786 & 0.8659 & 0.5703 & 0.4863 & \\
\hline $\mathrm{O}_{2}$ & 0.7266 & 1 & 0.7598 & 0.7021 & 0.726 & 0.5679 & 0.4805 & \\
\hline $\mathrm{O}_{3}$ & 0.7782 & 0.7668 & 1 & 0.7652 & 0.8038 & 0.5371 & 0.4568 & \\
\hline $\mathrm{O}_{4}$ & 0.7807 & 0.7102 & 0.7652 & 1 & 0.8239 & 0.4937 & 0.4237 & \\
\hline $\mathrm{O}_{5}$ & 0.8656 & 0.7308 & 0.8016 & 0.8218 & 1 & 0.534 & 0.4596 & \\
\hline $\mathrm{O}_{6}$ & 0.5635 & 0.5679 & 0.5267 & 0.4831 & 0.5276 & 1 & 0.7176 & \\
\hline $\mathrm{O}_{7}$ & 0.4894 & 0.4911 & 0.4568 & 0.4237 & 0.4635 & 0.7254 & 1 & \\
\hline \multicolumn{9}{|c|}{ Solvency } \\
\hline & $S_{1}$ & $S_{2}$ & $S_{3}$ & $S_{4}$ & $S_{5}$ & $S_{6}$ & $S_{7}$ & $S_{8}$ \\
\hline$S_{1}$ & 1 & 0.7126 & 0.7149 & 0.7078 & 0.6316 & 0.5089 & 0.7504 & 0.7536 \\
\hline$S_{2}$ & 0.7223 & 1 & 0.6679 & 0.6687 & 0.5829 & 0.5275 & 0.7842 & 0.7785 \\
\hline$S_{3}$ & 0.7196 & 0.6626 & 1 & 0.9375 & 0.7672 & 0.4232 & 0.7052 & 0.7087 \\
\hline$S_{4}$ & 0.7147 & 0.6659 & 0.9382 & 1 & 0.7664 & 0.4229 & 0.7056 & 0.7090 \\
\hline$S_{5}$ & 0.6426 & 0.5829 & 0.7712 & 0.7685 & 1 & 0.4043 & 0.6248 & 0.6259 \\
\hline$S_{6}$ & 0.5116 & 0.5176 & 0.4198 & 0.4167 & 0.395 & 1 & 0.4934 & 0.4898 \\
\hline$S_{7}$ & 0.7253 & 0.7526 & 0.6714 & 0.6697 & 0.5785 & 0.4553 & 1 & 0.9745 \\
\hline$S_{8}$ & 0.7287 & 0.7461 & 0.675 & 0.6734 & 0.5794 & 0.4516 & 0.9745 & 1 \\
\hline
\end{tabular}

2. To integrate a globalized GRA and DEMATEL, use the selection indicators in Table 2 to establish a direct-relation matrix $T$. Then, the total-relation matrix $Z$ can be obtained.

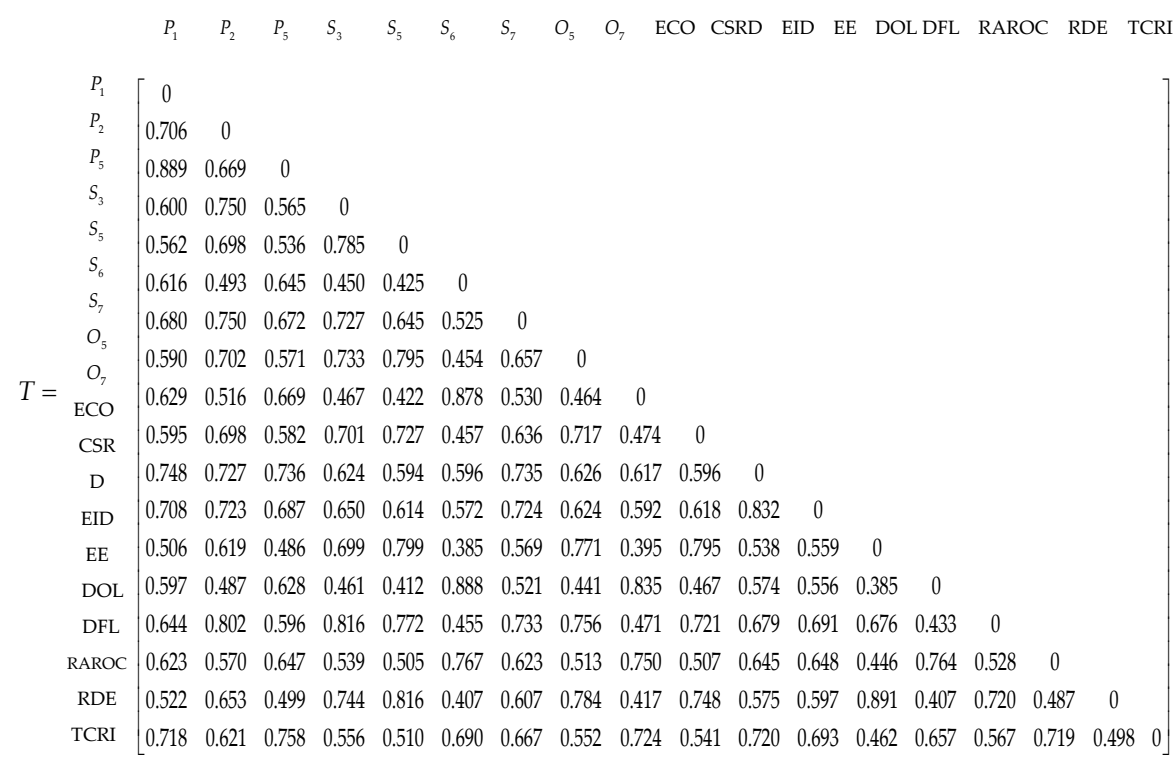




$$
Z=\left[\begin{array}{ccccc}
1.02945 & 1.11315 & 1.09355 & \cdots & 1.06176 \\
1.11316 & 1.08043 & 1.10023 & \cdots & 1.07737 \\
1.09355 & 1.10022 & 1.01056 & \cdots & 1.05579 \\
\vdots & \vdots & \vdots & \ddots & \vdots \\
1.06176 & 1.07736 & 1.05578 & \cdots & 0.94670
\end{array}\right]_{18 \times 18}
$$

3. To integrate a globalized GRA, DEMATEL and ANP, the weighted supermatrix $\left(W_{W}\right)$ was obtained by using "Super Decision 2.2". Then, the limit supermatrix can be obtained by the ANP method. A relative weight for each indicator can be obtained by limit supermatrix, as shown in Table A3.

$$
W_{W}=\left[\begin{array}{ccccc}
0.02835 & 0.06082 & 0.05855 & \cdots & 0.05723 \\
0.02621 & 0.05902 & 0.05887 & \cdots & 0.05360 \\
0.02667 & 0.06011 & 0.05411 & \cdots & 0.05810 \\
\vdots & \vdots & \vdots & \vdots & \vdots \\
0.05250 & 0.03042 & 0.05652 & \cdots & 0.05554
\end{array}\right]_{18 \times 18}
$$

Table A3. The weights of the indicators using a globalized GRA-DEMATEL-ANP.

\begin{tabular}{cccccccccc}
\hline Indicators & $\boldsymbol{P}_{\mathbf{1}}$ & $\boldsymbol{P}_{\mathbf{2}}$ & $\boldsymbol{P}_{\mathbf{5}}$ & $\boldsymbol{S}_{\mathbf{3}}$ & $\boldsymbol{S}_{5}$ & $\boldsymbol{S}_{\mathbf{6}}$ & $\boldsymbol{S}_{\mathbf{7}}$ & $\boldsymbol{O}_{5}$ & $\boldsymbol{O}_{7}$ \\
Weights & 0.05798 & 0.05902 & 0.05726 & 0.0576 & 0.0565 & 0.05175 & 0.05811 & 0.05707 & 0.05243 \\
\hline Indicators & ECO & CSRD & EID & EE & DOL & DFL & RAROC & RDE & TCRI \\
Weights & 0.05625 & 0.05872 & 0.05848 & 0.05363 & 0.0515 & 0.05887 & 0.0545 & 0.05538 & 0.04495 \\
\hline
\end{tabular}

Note: $P_{1}$ : return on assets, $P_{2}$ : return on equity, $P_{5}$ : net profit margin $S_{3}$ : current ratio, $S_{5}$ : long-term capital ratio, $S_{6}$ : times interest earned, $S_{7}$ : oper. income / capital, $O_{5}$ : turnover of net worth, $O_{7}$ : days-inventory turnover, ECO: eco-efficiency indicator, CSRD: CSR disclosures, EID: environment information disclosures, EE: environment expenditure, DOL: degree of operating leverage, DFL: degree of financial leverage, RAROC: risk-adjusted rate of return on capital, RDE: R\&D expenditure, TCRI: Taiwan corporate credit risk index.

4. Establish the normalized decision matrix $R$ for the TOPSIS analysis. Then, the weighted normalized decision matrix $V$ for each indicator can be calculated.

$$
\begin{gathered}
R=\left[\begin{array}{ccccc}
0.49793 & 0.29482 & 0.57488 & \cdots & 0.55556 \\
0.49615 & 0.24748 & 0.58166 & \cdots & 0.66667 \\
0.67180 & 0.40579 & 0.67997 & \cdots & 0.88889 \\
\vdots & \vdots & \vdots & \ddots & \vdots \\
0.00000 & 0.11308 & 0.00000 & \cdots & 0.55556
\end{array}\right]_{52 \times 18} . \\
V=\left[\begin{array}{ccccc}
0.02887 & 0.01740 & 0.03292 & \cdots & 0.02497 \\
0.02877 & 0.01461 & 0.03331 & \cdots & 0.02997 \\
0.03895 & 0.02395 & 0.03894 & \cdots & 0.03996 \\
\vdots & \vdots & \vdots & \ddots & \vdots \\
0.00000 & 0.00667 & 0.00000 & \cdots & 0.02497
\end{array}\right]_{52 \times 18} .
\end{gathered}
$$

5. Identify the positive idea solution $A^{+}=[0.05798,0.05902,0.05726, \ldots, 0.04495]_{1 \times 18}$ and the negative idea solution $A^{-}=[0,0,0, \ldots, 0]_{1 \times 18}$. Then, calculate the positive and negative ideal solutions $\left(S_{i}^{+}\right.$and $\left.S_{i}^{-}\right)$for each company, respectively.

6. 6. Calculate the relative closeness coefficient for each alternative. Then, rank the 55 companies according to the relative closeness coefficients. The results are shown in Table 3. 


\section{Appendix C. The Ranking Results of the Sensitivity Analysis}

In order to investigate the effect of the combined weight for the ranking results, we conducted a sensitivity analysis to evaluate the influence of weight. The results of the weights of the evaluation indicators used in the sensitivity analysis are shown in Table A4. The ranking results of the sensitivity analysis are shown in Table A5.

Table A4. The weights of evaluation indicators for using in sensitivity analysis.

\begin{tabular}{cccccccccc}
\hline Indicators & $\boldsymbol{P}_{\mathbf{1}}$ & $\boldsymbol{P}_{\mathbf{2}}$ & $\boldsymbol{P}_{\mathbf{5}}$ & $\boldsymbol{S}_{3}$ & $\boldsymbol{S}_{\mathbf{5}}$ & $\boldsymbol{S}_{\mathbf{6}}$ & $\boldsymbol{S}_{7}$ & $\boldsymbol{O}_{5}$ & $\boldsymbol{O}_{7}$ \\
Weights & 0.06407 & 0.07082 & 0.06299 & 0.06336 & 0.05368 & 0.04140 & 0.06973 & 0.06278 & 0.04981 \\
\hline Indicators & ECO & CSRD & EID & EE & DOL & DFL & RAROC & RDE & TCRI \\
Weights & 0.05344 & 0.07046 & 0.07018 & 0.05095 & 0.04120 & 0.07064 & 0.05178 & 0.05261 & 0.03596 \\
\hline
\end{tabular}

Table A5. The results of the sensitivity analysis.

\begin{tabular}{ccccccccccccccc}
\hline Companies & F1 & F2 & F3 & F4 & F5 & F6 & F7 & F8 & F9 & F10 & F11 & F12 & F13 & F14 \\
Rank & 51 & 42 & 5 & 3 & 14 & 38 & 24 & 16 & 11 & 7 & 13 & 39 & 52 & 1 \\
\hline Companies & F15 & F16 & F17 & F18 & F19 & F20 & F21 & F22 & F23 & F24 & F25 & F26 & F27 & F28 \\
Rank & 21 & 6 & 46 & 34 & 32 & 23 & 9 & 15 & 35 & 29 & 2 & 4 & 20 & 30 \\
\hline Companies & F29 & F30 & F31 & F32 & F33 & F34 & F35 & F36 & F37 & F38 & F39 & F40 & F41 & F42 \\
Rank & 17 & 26 & 18 & 19 & 47 & 53 & 36 & 22 & 27 & 8 & 28 & 40 & 10 & 44 \\
\hline Companies & F43 & F44 & F45 & F46 & F47 & F48 & F49 & F50 & F51 & F52 & F53 & F54 & F55 & \\
Rank & 50 & 45 & 37 & 43 & 12 & 55 & 33 & 41 & 49 & 25 & 54 & 31 & 48 & \\
\hline
\end{tabular}

\section{References}

1. Eccles, R.G.; Pyburn, P.F. Creating a comprehensive system to measure performance. Manag. Acc. 1992, 74, $41-44$.

2. Weber, O.; Scholz, R.W.; Michalik, G. Incorporating sustainability criteria into credit risk management. Bus. Strateg. Environ. 2010, 19, 39-50. [CrossRef]

3. Aruldoss, M.; Lakshmi, T.M.; Venkatesan, V.P. A survey on multi criteria decision making methods and its applications. Am. J. Inf. Syst. 2013, 1, 31-43.

4. Büyüközkan, G.; Arsenyan, J.; Ertek, G. Evaluation of e-learning web sites using fuzzy axiomatic design based approach. Int. J. Comput. Int. Syst. 2010, 3, 28-42. [CrossRef]

5. Kou, G.; Peng, Y.; Lu, C. MCDM approach to evaluating bank loan default models. Technol. Econ. Dev. 2014, 20, 292-311. [CrossRef]

6. Rostamzadeh, R.; Ismail, K.; Bodaghi Khajeh Noubar, H. An application of a hybrid MCDM method for the evaluation of entrepreneurial intensity among the SMEs: A case study. Sci. World J. 2014, 2014, 703650. [CrossRef] [PubMed]

7. Alam-Tabriz, A.; Rajabani, N.; Farrokh, M. An integrated fuzzy DEMATEL-ANP-TOPSIS methodology for supplier selection problem. Glob. J. Manag. Stud. Res. 2014, 1, 85-99.

8. Alimardani, M.; Rabbani, M.; Rafiei, H. A novel hybrid model based on DEMATEL, ANP and TOPSIS for supplier selection in agile supply chains. Int. J. Serv. Oper. Manag. 2014, 18, 179-211. [CrossRef]

9. Kuan, M.; Chen, Y. A hybrid MCDM framework combined with DEMATEL-based ANP to evaluate enterprise technological innovation capabilities assessment. Decis. Sci. Lett. 2014, 3, 491-502. [CrossRef]

10. Shen, K.Y.; Yan, M.R.; Tzeng, G.H. Combining VIKOR-DANP model for glamor stock selection and stock performance improvement. Knowl. Based Syst. 2014, 58, 86-97. [CrossRef]

11. Hsu, L.C. Investment decision making using a combined factor analysis and entropy-based TOPSIS model. J. Bus. Econ. Manag. 2013, 14, 448-466. [CrossRef]

12. Bulgurcu, B. Financial performance ranking of automotive industry firms in Turkey: Evidence from entropy weighted technique. Int. J. Econ. Financ. 2013, 3, 844-851.

13. Ghadikolaei, A.S.; Esbouei, S.K. Integrating fuzzy AHP and fuzzy ARAS for evaluating financial performance. Bol. Soc. Parana. Mat. 2013, 32, 163-174. [CrossRef] 
14. Ghadikolaei, A.S.; Esbouei, S.K.; Antucheviciene, J. Applying fuzzy MCDM for financial performance evaluation of Iranian companies. Technol. Econ. Dev. 2014, 20, 274-291. [CrossRef]

15. Moghimi, R.; Anvari, A. An integrated fuzzy MCDM approach and analysis to evaluate the financial performance of Iranian cement companies. Int. J. Adv. Manuf. Technol. 2014, 71, 685-698. [CrossRef]

16. Wang, Y.J. The evaluation of financial performance for Taiwan container shipping companies by fuzzy TOPSIS. Appl. Soft Comput. 2014, 22, 28-35. [CrossRef]

17. Sun, Y.F.; Wu, C.H. Green credit loan as environmental policy. Environ. Econ. 2010, 1, 68-75.

18. Li, J.L. Enterprises' environmental credit assessment-from the perspective of financial institutions' green credit. Adv. Mater. Res. 2012, 361, 1868-1873. [CrossRef]

19. Xu, L. On the evaluation of performance system incorporating "green credit" policies in China's financial industry. J. Financ. Risk Manag. 2013, 2, 33-37. [CrossRef]

20. Toloie-Eshlaghy, A.; Homayonfar, M. MCDM methodologies and applications: A literature review from 1999 to 2009. Res. J. Int. Stud. 2011, 21, 86-137.

21. Büyüközkan, G.; Çifçi, G. A novel hybrid MCDM approach based on fuzzy DEMATEL, fuzzy ANP and fuzzy TOPSIS to evaluate green suppliers. Expert Syst. Appl. 2012, 39, 3000-3011. [CrossRef]

22. Ou Yang, Y.P.; Shieh, H.M.; Tzeng, G.H. A VIKOR technique based on DEMATEL and ANP for information security risk control assessment. Inf. Sci. 2013, 232, 482-500. [CrossRef]

23. Ding, S.H.; Kamaruddin, S. Assessment of distance-based multi-attribute group decision-making methods from a maintenance strategy perspective. J. Ind. Eng. Int. 2014, 11, 73-85. [CrossRef]

24. Hassan, M.; Kamran, N.; Mohsen, M.C.; Vahidreza, M. Design of a combined fuzzy model in codifying and ranking strategies. Afr. J. Bus. Manag. 2012, 6, 11797-11808. [CrossRef]

25. Stanujkic, D.; Djordjevic, B.; Djordjevic, M. Comparative analysis of some prominent MCDM methods: A case of ranking Serbian banks. Serb. J. Manag. 2013, 8, 213-241. [CrossRef]

26. Ou, Y.C. Using a hybrid decision-making model to evaluate the sustainable development performance of high-tech listed companies. J. Bus. Econ. Manag. 2016, 17, 331-346. [CrossRef]

27. Hsu, L.C.; Ou, S.L.; Ou, Y.C. A comprehensive performance evaluation and ranking methodology under a sustainable development perspective. J. Bus. Econ. Manag. 2015, 16, 74-92. [CrossRef]

28. Hwang, R.C.; Chung, H.; Siao, J.S.; Lin, C.L. Does the local rating agency provide reliable credit ratings? An empirical analysis from an emerging market. J. Fixed Income 2012, 22, 41-51. [CrossRef]

29. Lu, S.L. Assessing the credit risk of bank loans using an extended Markov chain model. J. Appl. Financ. Bank. 2012, 2, 197-223.

30. Norman, W.; MacDonald, C. Getting to the bottom of "triple bottom line". Bus. Ethics Q. 2004, 14, $243-262$. [CrossRef]

31. Fujii, H.; Iwata, K.; Kaneko, S.; Managi, S. Corporate environmental and economic performances of Japanese manufacturing firms: Empirical study for sustainable development. Bus. Strateg. Environ. 2013, 22, 187-201. [CrossRef]

32. Grigoroudis, E.; Orfanoudaki, E.; Zopounidis, C. Strategic performance measurement in a healthcare organization: A multiple criteria approach based on balanced score. Omega 2012, 40, 104-119. [CrossRef]

33. Ittner, C.D.; Larcker, D.F. Coming up short on non-financial performance measurement. Harv. Bus. Rev. 2003, 81, 88-95. [PubMed]

34. Hsu, L.C. A hybrid multiple criteria decision-making model for investment decision making. J. Bus. Econ. Manag. 2014, 15, 509-529. [CrossRef]

35. Hsu, L.C. Using a decision-making process to evaluate efficiency and operating performance for listed semiconductor companies. Technol. Econ. Dev. 2015, 21, 301-331. [CrossRef]

36. Fu, G.; Wang, J.; Jia, M. The relationship between corporate social performance and financial performance: Modified models and their application: Evidence from listed companies in China. J. Contemp. Manag. 2013, 2, 17-37.

37. Karagiorgos, T. Corporate social responsibility and financial performance: An empirical analysis on Greek companies. Eur. Res. Stud. 2010, 13, 85-108.

38. Rundle-Thiele, S.; Ball, K.; Gillespie, M. Raising the bar: From corporate social responsibility to corporate social performance. J. Consum. Mark. 2008, 25, 245-253. [CrossRef]

39. Fauzi, H.; Svensson, G.; Rahman, A.A. "Triple bottom line" as "sustainable corporate performance": A proposition for the future. Sustainability 2010, 2, 1345-1360. [CrossRef] 
40. Elsakit, O.; Worthington, A. The attitudes of managers and stakeholders towards corporate social and environmental disclosure. Int. J. Econ. Financ. 2012, 4, 240-251. [CrossRef]

41. Yilmaz, İ. Social performance vs. financial performance: CSR disclosures as an indicator of social performance. Int. J. Financ. Bank Stud. 2013, 2, 53-65. [CrossRef]

42. Porter, M.E. The competitive advantage of the inner city. Harv. Bus. Rev. 1995, 73, 55-71.

43. Maxwell, J.; Rothenberg, S.; Briscoe, F.; Marcus, A. Green schemes: Corporate environmental strategies and their implementation. Calif. Manag. Rev. 1997, 39, 118-120. [CrossRef]

44. Chen, Y.S.; Lai, S.B.; Wen, C.T. The influence of green innovation performance on corporate advantage in Taiwan. J. Bus. Ethics 2006, 67, 331-339. [CrossRef]

45. King, A.A.; Lenox, M.J. Does it really pay to be green? An empirical study of firm environmental and financial performance: An empirical study of firm environmental and financial performance. J. Ind. Ecol. 2001, 5, 105-116. [CrossRef]

46. López-Gamero, M.D.; Molina-Azorín, J.F.; Claver-Cortés, E. The whole relationship between environmental variables and firm performance: Competitive advantage and firm resources as mediator variables. J. Environ. Manag. 2009, 90, 3110-3121. [CrossRef] [PubMed]

47. Wang, W.K.; Lu, W.M.; Wang, S.W. The impact of environmental expenditures on performance in the U.S. chemical industry. J. Clean. Prod. 2013, 64, 447-456. [CrossRef]

48. Aerts, W.; Cormier, D.; Magnan, M. Corporate environmental disclosure, financial markets and the media: An international perspective. Ecol. Econ. 2008, 64, 643-659. [CrossRef]

49. Charles, H.C.; Martin, F.; Dennis, M.P. Corporate disclosure of environmental capital expenditures: A test of alternative theories. Account. Audit. Account. J. 2012, 25, 486-507.

50. Leiter, A.M.; Parolini, A.; Winner, H. Environmental regulation and investment: Evidence from European industry data. Ecol. Econ. 2011, 70, 759-770. [CrossRef]

51. Patten, D.M. The relation between environmental performance and environmental disclosure: A research note. Account. Org. Soc. 2002, 27, 763-773. [CrossRef]

52. Verrecchia, R.E. Discretionary disclosure. J. Acc. Econ. 1983, 5, 179-194. [CrossRef]

53. Christmann, P.; Taylor, G. Globalization and the environment: Determinants of firm self-regulation in China. J. Int. Bus. Stud. 2001, 32, 439-458. [CrossRef]

54. Dean, T.J.; Brown, R.L. Pollution regulation as a barrier to new firm entry: Initial evidence and implications for future research. Acad. Manag. J. 1995, 38, 288-303.

55. Yoon, K.P.; Hwang, C.L. Multiple Attribute Decision Making: An Introduction; Sage Publications: Thousand Oaks, CA, USA, 1995.

56. Kung, C.Y.; Wen, K.L. Applying grey relational analysis and grey decision-making to evaluate the relationship between company attributes and its financial performance-A case study of venture capital enterprises in Taiwan. Decis. Support Syst. 2007, 43, 842-852. [CrossRef]

57. Özdağoğlu, A.; Gümüş, Y.; Özdağoğlu, G.; Gümüş, G.K. Evaluating financial performance with grey relational analysis: An application of manufacturing companies listed on Borsa İstanbul. Muhasebe ve Finansman Dergisi 2017, 73, 289-312. [CrossRef]

58. Malek, A.; Ebrahimnejad, S.; Tavakkoli-Moghaddam, R. An improved hybrid grey relational analysis approach for green resilient supply chain network assessment. Sustainability 2017, 9, 1433. [CrossRef]

59. Kuo, T. A review of some modified grey relational analysis models. J. Grey Syst. 2017, 29, 70-77.

60. Wang, Y.J. Combining grey relation analysis with FMCGDM to evaluate financial performance of Taiwan container lines. Expert Syst. Appl. 2009, 36, 2424-2432. [CrossRef]

61. Sa, B.; Mb, S.; Pasupathy, S.A.; Karthick Kumar, K.; Ge, S. Multi objective optimization of anaerobic digestion of poultry litter using Taguchi grey relational analysis. Int. J. Appl. Eng. Res. 2018, 13, 5216-5222.

62. Deng, J.L. Control problems of grey systems. Syst. Control Lett. 1982, 1, 288-294.

63. Shao, Q.G.; Liou, J.J.; Weng, S.S.; Chuang, Y.C. Improving the green building evaluation system in China based on the DANP method. Sustainability 2018, 10, 1173. [CrossRef]

64. Moghassem, A.R.; Fallahpour, A.R. Selecting doffing tube components for rotor-spun yarn for weft knitted fabrics using multi-criteria decision-making approach with interval data. J. Eng. Fiber Fabr. 2011, 6, 44-53. [CrossRef]

65. Moghassem, A.R. Comparison among two analytical methods of multi-criteria decision making for appropriate spinning condition selection. World Appl. Sci. J. 2013, 21, 784-794. 
66. Yu, V.F.; Hu, K.J. An integrated fuzzy multi-criteria approach for the performance evaluation of multiple manufacturing plants. Comput. Ind. Eng. 2010, 58, 269-277. [CrossRef]

67. Feng, C.M.; Wang, R.T. Performance evaluation for airlines including the consideration of financial ratios. J. Air Transp. Manag. 2000, 6, 133-142. [CrossRef]

68. Ballı, S.; Korukoğlu, S. Development of a fuzzy decision support framework for complex multi-attribute decision problems: A case study for the selection of skilful basketball players. Expert Syst. 2014, 31, 56-69. [CrossRef]

69. Chakraborty, R.; Ray, A.; Dan, P. Multi criteria decision making methods for location selection of distribution centers. Int. J. Ind. Eng. Comput. 2013, 4, 491-504. [CrossRef]

(C) 2019 by the authors. Licensee MDPI, Basel, Switzerland. This article is an open access article distributed under the terms and conditions of the Creative Commons Attribution (CC BY) license (http:/ / creativecommons.org/licenses/by/4.0/). 